\title{
PATHOGENESIS OF IRIDOVIRUS: \\ IN VITRO INFLUENCE ON MACROPHAGE ACTIVITY AND CYTOKINE-LIKE PROTEIN PRODUCTION IN FISH
}

\author{
A. SIWICKI ${ }^{1}$, F. POZET $^{2}$, M. MORAND ${ }^{2}$, E. TERECH-MAJEWSKA ${ }^{3}$ D. BERNARD ${ }^{2}$ \\ ${ }^{1}$ Department of Microbiology and Clinical Immunology, \\ Faculty of Veterinary Medicine University of Olsztyn, 10-957 Olsztyn, Poland \\ ${ }^{2}$ Laboratoire Departmental d'Analyses (LDA 39 ), Conseil General du Jura, \\ 39016 Lons le Saunier, France \\ ${ }^{3}$ Department of Epizootiology with Clinic of Infection Diseases, \\ Faculty of Veterinary Medicine, University of Olsztyn, 10-957 Olsztyn, Poland
}

Received March 26, 2001

Accepted August 28, 2001

\section{Abstract}

Siwicki A., F. Pozet, M. Morand, E. Terech-Majewska, D. Bernard: Pathogenesis of Iridovirus: in Vitro Influence on Macrophage Activity and Cytokine-Like Protein Production In Fish. Acta Vet. Brno, 2001, 70: 451-456.

In recent years, iridovirus-like agents have been recognized as the cause of several diseases in fish. An iridovirus-like pathogen isolated from catfish (Ictalurus melas) was tested in vitro on the macrophage activity and cytokine-like protein (IL-1, IL-6) production in carp (Cyprinus carpio L.), rainbow trout (Oncorhynchus mykiss) and sheatfish (Silurus glanis L.). The influence of the iridovirus on pronephric macrophage activity was examined by studying the respiratory burst activity (RBA) and potential killing activity (PKA) as well as the production of cytokines by pronephric leukocytes stimulated by ConA. The results showed that iridovirus decreased the RBA and PKA in carp, rainbow trout and sheatfish. The highest inhibitory effect was observed in sheatfish ( $70 \%$ of activity), compared to carp (35\% activity) and rainbow trout (20\% activity). The production of cytokines by pronephric leukocytes had a similar pattern. The results showed that iridovirus decreased significantly $(P<0.05)$ the IL-1-like protein and IL-6-like protein production and the highest inhibitory influence in sheatfish was observed. This preliminary in vitro comparative study demonstrated a suppressive influence of the iridovirus-like pathogen on macrophage activity and cytokine-like protein production in carp, rainbow trout and sheatfish, but the highest immunosuppressive effect was observed in sheatfish.

Iridovirus, fish, macrophage, cytokines, RBA, PKA

Iridoviruses, large double-stranded cytoplasmic DNA viruses, infect different insect and vertebrate hosts. The major structural component of the non-enveloped icosahedral virus particles is the major capsid protein, which appears to be highly conserved among members of the family Iridoviridae, Phycodnaviridae and African swine fever virus. There are cytoplasmic DNA viruses that appear to be distantly related to iridoviruses including members of the family Phycodnaviridae which infect endosymbiotic algae and African swine fever virus (Coggiu s 1974; A hne et al. 1990). The common property of these DNA viruses is that essential steps of transcription, replication and assembly take place in the cytoplasm of the host cells. The experimental study showed that cytoplasmic DNA viruses need the cell nucleus for productive infection (Ahne et al. 1997). One of the most interesting features of iridoviruses, that African swine fever virus and phycodnaviruses, is the significant homology between the amino acid sequences of their major capsid protein (Ahne et al. 1997; Tidona et al.1998). Vertebrate iridoviruses are found in fish, amphibians and reptiles. Many new iridoviruses-like agents have been described in different species of fish. Their morphological and biological characteristics clearly separate them

Address for correspondence:

Professor Andrzej K. Siwicki DVM, PhD, DSc

Department of Microbiology and Clinical Immunolog $10-957$ Olsztyn- Kowo II, Poland
Phone: +48227562490

Fax: +48227562490

E-miticki@inom.edu.pl

http//www.vfu.cz/acta-vet/actavet.htm 
from the fish iridovirus associated with lymphocystis disease (LD), epizootic haematopoietic necrosis (EHN) and epidermal infections. To date, the mechanisms involved in the iridoviruses penetration into fish are not understood. The experimental study presented that the most severe lesions were found in the pronephros, spleen, and vascular system. The most characteristic feature of iridovirus infection was a generalized acute necrosis of the renal haematopoietic tissue. Macrophages and neutrophils in the interstitial tissue harboured virus particles in their phagosomes. Residual degenerating haematopoietic cells showed numerous iridovirus particles and cytoplasmic viral subunit assemblies were observed (Ahne et al. 1990; Ahne et al. 1997).

This study reports the preliminary results of the in vitro effects of iridovirus on the macrophage activity and IL-1-like protein and IL-6-like protein production by mitogenstimulated leukocytes in carp, rainbow trout and sheatfish.

\section{Materials and Methods}

Animals and cells separation

The pronephros were isolated and cells culture were performed from healthy carp (Cyprinus carpio L.), rainbow trout (Oncorhynchus mykiss) and sheatfish (Silurus glanis L.) with a mean weight $100 \mathrm{~g}$, according to the method presented by Bayne (1985) and for salmonid by Secombes (1990). Before dissection, the 20 fish from each species were anaesthetized in Propiscin (IFI, Poland) and bled from the caudal vein (Vacutainer systems, Bencton Dickinson) to reduce the blood volume in the pronephros. Single cell suspensions were obtained by placing the pronephros in RPMI-1640 (Sigma) medium and teasing it through a steel mesh. They were isolated on Histopaque1077 (Sigma) or Ficoll-Paque (density $1.077 \mathrm{~g} / \mathrm{ml}$ ), Pharmacia) gradients.

\section{Cell line and virus}

The Laboratoire Departemental d'Analyses (LDA 39) France iridovirus (59.90) isolated from catfish (Ictalurus melas) was used in this in vitro experimental study and quantified by plaque assay using the Epithelioma papulosum cyprini (EPC) cells incubated at $20^{\circ} \mathrm{C}$ for $72 \mathrm{~h}$. The EPC cell line in MEM (BHK21 Medium, Glasgow minimum essential medium, Life Technologies, USA) with $10 \%$ tryptose phosphate broth (Difco) and $10 \%$ foetal calf serum (FCS, Life Technologies) was used to grow the iridovirus, according to the method presented by Pozet et al. (1992). For virus production, the FCS content of the medium was reduced to $2 \%$ and the $\mathrm{pH}$ adjusted to 7.6 (Pozet et al. 1992).

Immunological assays

A modification of the Secombes (1990) method was used to study the respiratory burst activity (RBA) of the pronephric macrophages stimulated by Phorbol myristate acetate (PMA, Sigma; stock solution: $50 \mu \mathrm{g} / \mathrm{ml}$ in ethanol, kept frozen at $\left.-20^{\circ} \mathrm{C}\right)$. Cell suspension $(100 \mu \mathrm{l}$; at concentration $1 \times 106 /$ well in RPMI-1640) were distributed to 96-well culture plates (Nunclon) and incubated with $20 \mu 1$ of $1 \times 10^{5}$ plaque-forming units $/ \mathrm{ml}$ RPMI-1640 of virus for $2 \mathrm{~h}$ at $20^{\circ} \mathrm{C}$ for carp and sheatfish cells and $14{ }^{\circ} \mathrm{C}$ for rainbow trout cells. After incubation, the non-adherent cells were removed by washing in RPMI medium. The medium was replaced with $100 \mathrm{ml}$ of RPMI, and $100 \mathrm{ml}$ of nitro blue tetrazolium (NBT Sigma) solution $(2 \mu \mathrm{g} / \mathrm{ml}$ in RPMI) with or without PMA (Sigma). The plates were incubated $30 \mathrm{~min}$ at $20^{\circ} \mathrm{C}$ for carp and sheatfish or $14{ }^{\circ} \mathrm{C}$ for rainbow trout and after removed NBT solution wells were washed thoroughly with metanol. In order to measure $\mathrm{H}_{2} \mathrm{O}_{2}$ production, the plates were read with a micro reader (Optical density $620 \mathrm{~nm}$; Labsystems iEMS Reader MF, Finland).

A modification by Siwicki and Anderson (1993) of the technique presented by Rook et al. (1985) was used to measure the potential killing activity (PKA) of pronephric macrophages. The macrophages were stimulated with $0.2 \%$ NBT (Sigma, USA) solution in PBS containing living Aeromonas hydrophila $\left(1 \times 10^{8}\right.$ bacteria/ml $)$ and incubated for $30 \mathrm{~min}$ at $20^{\circ} \mathrm{C}$. The plates were read in a micro reader (Optical density $620 \mathrm{~nm}$; Labsystems iEMS Reader MF, Finland).

In the second part of our preliminary in vitro study, the influence of iridovirus (59.90) on the interleukin 1-like protein (IL-1-like protein) and interleukin 6-like protein (IL-6-like protein) production by pronephros leukocytes isolated from carp, rainbow trout and sheatfish was investigated, according to the method previously presented by Ahne (1994). The pronephros leukocytes from 20 fish of each species were separated and distributed (1 ml) in $24-$ well plates (Nunclon) at concentration $1 \times 10^{6}$ cells $/ \mathrm{ml}$ of RPMI-1640 medium supplemented with $10 \%$ foetal calf serum (FCS, Life Technologies) and incubated $1 \mathrm{~h}$ with: ConA $(20 \mu \mathrm{g} / \mathrm{ml}$ RPMI), ConA + iridovirus (at doses of $1 \times 10^{5}$ plaque-forming units/ml RPMI), and only iridovirus at a temperature of $20{ }^{\circ} \mathrm{C}$. The control was cells in medium RPMI supplemented with $10 \%$ FCS. After incubation supernatant from cells suspension were removed and stored at $-20^{\circ} \mathrm{C}$ prior to assay. The levels of the interleukins IL-1-like protein and IL-6-like protein have been evaluated using the ELISA assay (Genzyme kits, USA). 
Statistical analysis

For statistical analysis, means and standard deviations for all test values were calculated, and Student's $t$-test was used to determine differences between two or more groups. The significance level used was $P<0.05$.

\section{Results}

In the present study, we analysed the influence of the iridovirus isolated from catfish on the pronephros macrophage activity and cytokine production in three species of fish: carp, rainbow trout and European catfish (sheatfish). The effects of iridovirus on macrophage respiratory burst activity (RBA) stimulated by PMA in carp, rainbow trout and sheatfish are presented in Fig. 1. The results showed that iridovirus significantly decreased $(P<0.05)$ the macrophage metabolism in three examined fish, compared to the control. The highest suppressive effect on macrophage activity level in sheatfish was observed (69\% reduction of their activity), compared to the carp ( $28 \%$ reduction) and rainbow trout (20\% reduction).

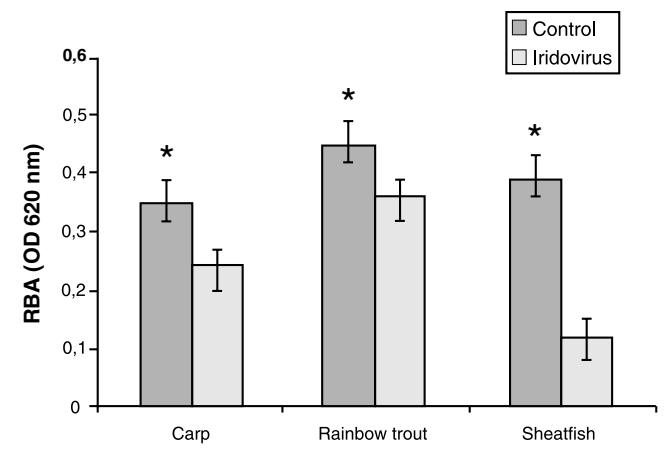

Fig. 1. In vitro influence of an iridovirus-like agent on carp, rainbow trout and sheatfish macrophage respiratory burst activity (RBA) (mean \pm S.D.; $\mathrm{n}=20 ; * P<0.05)$.

The phagocytic ability of pronephros macrophages showed a similar pattern. The influence of iridovirus on the macrophage potential killing activity (PKA) is presented in Fig. 2. The analysis of the effect of the iridovirus on killing activity of pronephros macrophages showed that the iridovirus significantly decreased $(P<0.05)$ the phagocytic ability of macrophages. The highest suppressive effect was observed in sheatfish (reduction of $70 \%$ activity), compared to carp (35\%) and rainbow trout $(20 \%)$.

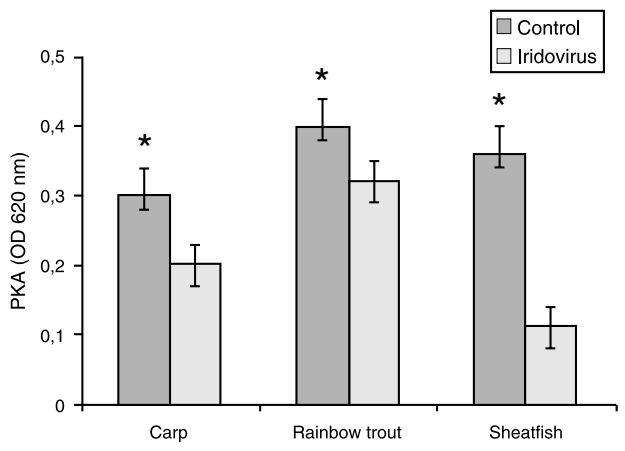

Fig. 2. In vitro influence of an iridovirus-like agent on carp, rainbow trout and sheatfish macrophage potential killing activity (PKA) (mean \pm S.D.; $\mathrm{n}=20 ; * P<0.05)$. 
In the second part of our study, we analysed the influence of iridovirus on IL-1-like protein and IL-6-like protein production by pronephric leukocytes of carp, rainbow trout and sheatfish. The amounts (pg/ml) of IL-1-like protein and Il-6-like protein produced by stimulated (ConA, ConA+iridovirus, and only iridovirus) and non-stimulated cells were measured. The IL-1-like protein and IL-6-like protein were generated by ConA-stimulated or virus-stimulated cells but not by non-stimulated cells. The influence of iridovirus on the IL-1-like protein production by pronephros leukocytes isolated from carp, rainbow trout and sheat fish and stimulated by mitogen ConA are presented in Fig. 3, and the influence of these virus on the IL-6-like protein production by pronephros leukocytes isolated from carp, rainbow trout and sheatfish and stimulated by ConA are presented in Fig. 4. Analysis of the results shows significant differences production $(P<0.05)$ of IL-1-like protein and IL-6-like protein between cells stimulated by ConA + infected by virus and only stimulated by ConA. The lowest levels of IL1-like protein and IL-6-like protein in sheatfish was observed, compared to carp and rainbow trout. The iridovirus significantly reduced $(P<0.05)$ the IL-1-like protein and IL-6-like protein production by pronephric leukocytes stimulated by ConA, but the highest reduction in sheatfish was observed.

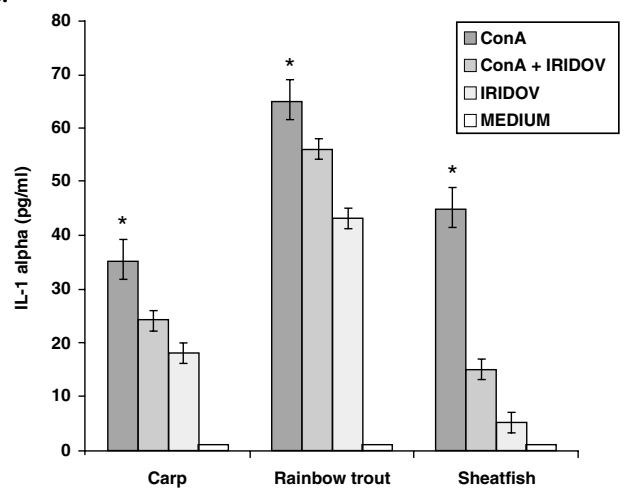

Fig. 3. In vitro influence of an iridovirus-like agent applied either with the mitogen (ConA+IRIDOV) or alone (IRIDOV) on IL-1a production by pronephros leukocytes of carp, rainbow trout and sheatfish (mean \pm S.D.; $\mathrm{n}=20$; $* P<0.05$ ).

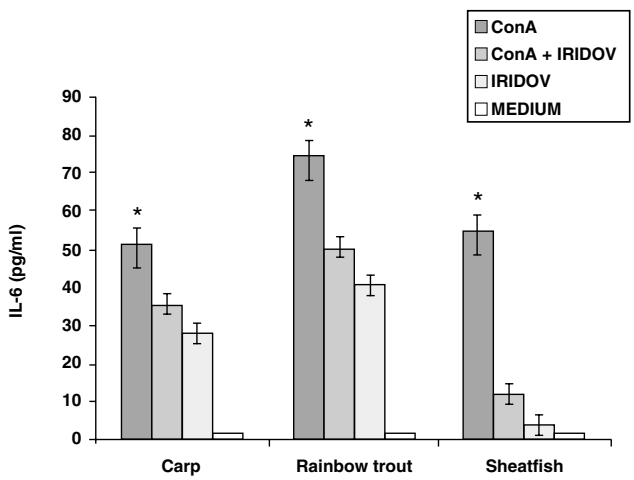

Fig. 4. In vitro influence of an iridovirus-like agent applied either with the mitogen (ConA+IRIDOV) or alone (IRIDOV) on IL-6 production by pronephros leukocytes of carp, rainbow trout and sheatfish (mean \pm S.D.; $n=20$; $* P<0.05)$.

This study also showed that iridovirus in vitro induced the IL-1-like protein and IL-6-like protein production by pronephros leukocytes of carp, rainbow trout and 
sheatfish. As shown in Figs 3 and 4, IL-1-like protein and IL-6-like protein were produced by iridovirus-infected cells but not by non-infected cells. However, the levels of the interleukin-like proteins secreted by iridovirus infected cells was significantly higher compared to the non-infected cells, but the lowest level of IL-1like protein and IL-6-like protein in sheatfish was observed, compared to the carp and rainbow trout.

\section{Discussion}

The mechanisms involved in the establishment of iridovirus infection are not well understood. We did not yet have the opportunity to prove the pathogenicity of the isolated iridovirus. Members of the family Iridoviridae infect different insect and vertebrate hosts causing a variety of symptoms ranging from inapparent infection to lethal disease. Iridoviruses were first described in crane fly larvae (Tipula paludosa) causing lethal infection. Subsequently, a number of other arthropods were identificated to be infected with iridovirus-like agents. The occurrence of iridescent virus diseases in some important vector species attracted the attention to this virus family as potential agents for biological control. Iridoviruses have been detected in more than hundred different species of lower vertebrates, especially in teleost fish (Ahne et al. 1990; Ahne et al. 1997; Coggius 1974). Most of the agents were described as lymphocystis viruses causing hypertrophy of infected connective tissue cells of the skin and viscera of fish. A second worldwide-distributed iridovirus disease causes erythrocytic necrosis. Also iridovirus have been isolated from carp inducing gill necrosis (Schelkunov and Schelkunova 1984), from rainbow trout and perch causing necrosis of the haematopoietic tissue (Langton et al. 1988; Hedrick et al. 1992) and from sheatfish causing haemorrhages and necrosis of liver, pancreas, gastrointestinal tract, and haematopoietic tissue (Ogawa et al. 1990; Ahne et al. 1997). Best example for the systemic iridovirus infection resulting in mortalities in homeothermic vertebrates is the African swine fever (Coggius 1974).

This preliminary in vitro comparative study demonstrated a strong inhibitory influence of iridovirus on the pronephric macrophage activity in carp, rainbow trout and sheatfish and suggested that the iridovirus induced a suppressive influence on cellmediated immunity. The several experimental studies suggested that fish viruses had a direct influence on the immunocompetence cell activity. Estapa et al. (1992) presented that viral haemorrhagic septicaemia virus (VHSV) replicates within rainbow trout macrophages. Also Chilmonczyk et al. (1995) clearly demonstrated a suppressive effect of VHSV on the phagocyte populations and phagocytic function. Our comparative study also suggested that there exists differentiation in anti-iridovirus protection dependent on the fish species. Analysis of these results strongly suggested that highest suppressive influence of iridovirus-like agent on sheatfish macrophage activity was observed, compared to carp and rainbow trout.

The effect of the viruses on the production of cytokines in fish has been shown by Ahne (1994ab). The author suggested that the cell metabolism have been turned down because of the VHSV infection leading to impaired production of interleukin-like proteins. The results of the present preliminary in vitro comparative study demonstrate a strong inhibitory influence of iridovirus on the IL-1-like protein and IL-6-protein production by pronephros leukocytes and suppressive effect dependant of fish species was observed. It looks like that one influence of the early-induced iridovirus pathogenecity is the diminished cytokine-like protein production by macrophages. These metabolic events should have an influence on the viral antigen processing by macrophages. 


\section{Patogeneze iridovirů: vliv na aktivitu makrofágů a produkci cytokine-like proteinu u ryb in vitro}

$\mathrm{V}$ posledních letech byly zárodky podobné iridovirům identifikovány jako příčina několika nemocí ryb. Patogen podobný iridoviru z Ictalurus melas byl testován in vitro na aktivitu makrofágů a produkci cytokine-like proteinu (IL-1, IL-6) u kapra (Cyprinus carpio), pstruha duhového (Oncorhynchus mykiss) a sumce velkého (Silurus glanis L.). Vliv iridoviru na aktivitu makrofágů $\mathrm{v}$ pronefros byl sledován pomocí respiratory burst activity (RBA) a potential killing activity (PKA) a také pomocí produkce cytokinů leukocyty z peronefros po stimulaci ConA. Nejvyšší inhibiční aktivita byla nalezena u sumce velkého $(70 \%)$ ve srovnání s kaprem $(35 \%)$ a pstruhem duhovým $(20 \%)$. Produkce cytokinů leukocyty z pronefros měla podobný průběh. Iridovirus významně snížil produkci proteinu podobného IL-1 a IL-6. Nejvyšší inhibiční vliv byl pozorován u sumce velkého. Tato předběžná studie in vitro prokázala supresivní efekt patogenu podobného iridoviru na aktivitu makrofágů a produkci cytokine-like proteinu u kapra, pstruha duhového a sumce velkého, u něhož byl imunosupresivní efekt nejvýraznější.

\section{References}

AHNE, W., OGAWA, M., SCHLOTFELDT, H. J. 1990: Fish viruses: Transmission and pathogenicity of an icosahedral cytoplasmic deoxyribovirus isolated from sheatfish (Silurus glanis). J. Vet. Med. 37:187-190

AHNE, W. 1994a: Lectin (ConA) induced interleukin (IL-1a, IL-2, IL-6) production in vitro by leukocytes of rainbow trout (Oncorhynchus mykiss). Bull. Eur. Ass. Fish Pathol. 14:33-35

AHNE, W. 1994b: VHSV induced impairment of interleukin (IL-1a, IL-2, IL-6) production by mitogen-stimulated leukocytes of rainbow trout (Oncorhynchus mykiss). Bull. Eur. Ass. Fish Pathol. 14:67-68

AHNE, W., BREMONT, M., HEDRICK, R. P., HYATT, A. D., WHITTINGTON, R. J. 1997: Special topic review: Iridoviruses associated with epizootic haematopoietic necrosis (EHN) in aquaculture. World J. Microbiol. Biotechnol. 13:367-373

BAYNE, C. J. 1985: Pronephric leucocytes of Cyprinus carpio: isolation, separation and characterization. Vet. Immunol. Immunopathol. 12:141-143

CHILMONCZYK, S., VOCCIA, I., MONGE, D. 1995: Pathogenesis of viral haemorrhagic septicemia virus: cellular aspects. Vet. Res. 26:505-511

COGGIUS, L. 1974: African swine fever virus. Pathogen. Prog. Med. Virol. 18: 48-50

ESTAPA, A., FRIAS, D., COLL, J. M. 1992: Susceptibility of trout kidney macrophages to viral haemorrhage septicemia virus. Viral. Immunol. 4:283-292

HEDRICK, R. P., MCDOWELL, T. S., AHNE, W., TORHY, C., DEKINKELIN, P. 1992: Properties of three iridovirus-like agents associated with systemic infections of fish. Dis. Aquat. Org. 13:203-209

LANGTON, J. S., HUMPHREY, J. D., WILLIAMS, M. L. 1988: Outbreaks of an EHNV-like iridovirus in cultured rainbow trout, Salmo gairdneri Richardson, in Australia. J. Fish Dis. 11:93-96

OGAWA, M., AHNE, W., FISCHER-SCHERL, T., HOFFMANN, R. W., SCHLOTFELDT, H. J. 1990: Pathomorphological alterations in sheatfish fry Silurus glanis experimentally infected with an iridovirus-like agent. Dis. Aquat. Org. 9:187-191

POZET, F., MORAND, M., MOUSSA, A., TORHY, C., DEKINKELIN, P. 1992: Isolation and preliminary characterization of a pathogenic icosahedral deoxyribovirus from the catfish, Ictalurus melas. Dis. Aquat. Org. 14:35-42

ROOK, G. A., STEELE, J., UMAR, S., DOCKREL, L. 1985: A simple method for the solubilization of reduced NBT, and its use as a colorimetric assay for activation of human macrophages by gamma-interferon. J. Immunol. Meth. 82:161-167

SECOMBES, C. J. 1990: Isolation of salmonid macophages and analysis of their killing activity. Tech. Fish Immunol. 1:137-154

SCHELKUNOV, J. S., SCHELKUNOVA, T. I. 1984: Results of virological studies on gill necrosis. Symp. Biol. Hungarica 23:31-43

SIWICKI, A. K., ANDERSON, D. P. 1993: Nonspecific defense mechanisms assay in fish. II. Potential killing activity of neutrophils and macrophages, lisozyme activity in serum and organs and total immunoglobulin (Ig) level in serum. In: Fish Diseases Diagnosis and Prevention Methods. FAO-Project GCP/INT/526/JPN, IFI Olsztyn Poland, pp. 105-112

TIDONA, C. A., SCHNITZLER, P., KEHM, R., DARAI, G. 1998: Is the major capsid protein of iridoviruses a suitable target for the study of viral evolution. Virus Genes 16:59-66 